\title{
Reflections on the Construction of Modern Chinese Universities’ Academy System
}

\author{
Dong Zhuoning ${ }^{1, a^{*}}$ \\ ${ }^{1}$ the Department of Student Affairs, Beihang University, College Road, Beijing, China \\ a dongzhuoning@buaa.edu.cn \\ * corresponding author
}

Keywords: academy system, implementation approaches, connotations.

\begin{abstract}
After clarifying the development of modern Chinese Academy system, the present study digs into its essence and connotations, and illustrates the multiple meanings of implementing Academy system. Finally, based on the educational philosophy and talents cultivation objectives of Chinese universities' Academy system, this paper proposes implementation approaches and policy suggestions, which are meaningful in promoting the development of Chinese universities' Academy system.
\end{abstract}

\section{Introduction}

Recent years, in the tide of Chinese reform of higher education, some universities attempted to carry out the educational management of Academy system one by one. Modern new Academies sprung up in the ascendant. In this critical moment, it is of great practical significance in disentangling the development and essence of modern Academy system as well as the exploring Chinese educational philosophy and talents cultivation objectives.

\section{Defining Modern Academy System}

Referring to the residential college mode and absorbing the quintessence of Chinese classical academy system, modern Academy system in China is established under the framework and concepts of modern university system. To identify the essence of Academy system, the following facts must be clarified:

\subsection{Modern Academy System is not Directly Inherited from Chinese Classic Academy System}

Classic academy system started from Tang dynasty and lasted for more than a thousand years, focusing on the morality education of loyalty, filial duty, honesty, and integrity. Because of the large gaps in educational background and era development, modern Academy system has changed tremendously-emphasizing both arts and science in terms of education notions, and moving forward from single "professional education" to "general +professional education". Modern Academy system is not the private institutions for imparting morality or feudal official organizations for compiling books any more, but the educational organization accelerating integrated development.

\subsection{Modern College System is not a Simple Copy of the Western Residential College System}

Residential college system was born in particular historic conditions of medieval Europe, inherited and developed by universities like Oxford, Cambridge, Harvard, and Yale. At that time, residential colleges emerged even earlier than universities. In contrast, colleges and universities in mainland China were established based on national situation and the reform of higher education, fully referring to the merits of western residential college system, exploring modern Academy system reform which differs enormously with the western residential colleges in the objectives of cultivating talents and the orientations of students' affairs. Universities in mainland China should not stick to the conventions but to develop modern Academy system combining universities own 
cultural construction with Chinese characteristics.

\subsection{Not All the So Called “Academies” are Academies}

Social academy organizations learn from the classic academy system more in the cultural traditions and humanistic implication, which differs greatly with modern Academy system and does not belong to higher education. In mainland China, more and more organizations are called "Academy" while only some of them have the basic characters of modern Academy system and made a theoretical foundation for the cultivation function of Academies. In this sense, the name is not important.

\section{The Significance of Academy System}

\subsection{From the Perspective of Cultivating Top-notch Creative Talents}

First, men are cultivated before talents. Academy should focus not only on individualized education but also general education. Individuality is the bedrock of creative mindset and the core of creativity. As a result, creativity cannot survive without individuality. The development of individuality and personal potential can enhance people to be well-rounded, and thus achieve their unique ingenious value. Meanwhile, general education with humanity spirit provides thick soil for training individuality. Students learn not only what can be applied into economic production immediately but also humanistic knowledge [1]. Academy creates erudite and elegant environment, coordinate resources inside and outside courses, support general education, and thus create a new education pattern with the same frequency resonance of professional education.

Second, attach importance to the penetrating function of the multiple learning and living environment of Academy. Through planning functional layout, academy implements crossaccommodation for students from multiple majors, constructs a diversified learning and living community, strengthens the environmental affection and provides the space for students' self-management, brings a good environment for freedom discussion, independent thinking, and creativity. Taking students living community as a "preview" of social life is a way to realize the cultural and educational living community, to share the public space for teachers and students, and to provide self-management education platform for students [2].

\subsection{From the Concepts and Thoughts of Students' Affairs}

First, realize the integration of students' affairs and teaching task to construct an academic community outside classroom. As the deepening of education and teaching reform, Academy breaks the traditional dualistic education pattern of inside and outside classroom, and constructs the third classroom-extending of first classroom (knowledge classroom) and expanding the second classroom (practical classroom). The extending classroom aims to form a comprehensive curriculum system combining general and professional knowledge, technology and humanity. The expanding classroom aims to strengthen both the engineering and social practice simultaneously, enhance students' humanistic feelings and comprehensive ability so that the join forces can be built and the integration of both teaching and cultivating can be achieved [3].

Second, uphold the concept of all-member education and strengthen the guidance of both mentality and knowledge to create a micro-"eco-circle" of teachers and students. Interaction between teachers and students is the most beautiful melody on campus. Mentors in Academy should share university life with their students in the form of special courses, social practice guidance and special activities, and design various learning environments based on students' characteristics and needs for them to choose. Reinforced interaction between teachers and students can form an intellective, social and cultural communication, which transforms mandatory instilling into positive education. Thus, a mutual respect, mutual trust and mutual friendship can be established. In the relaxed and harmonious relationship between teachers and students, the mentors take care of students invisibly by influencing students with noble morality and academic attitude, benefiting both teaching and learning, and guiding students to grow into capable talents. 


\subsection{From the Reform of Students' Organization and Mobilization Patterns}

First, the organization patterns of students especially the freshmen and sophomore as well as the development of the transition of whole students' affairs should change according to the reform of education facing the new situation of broad category enrollment, broad category cultivation, complete credit system, and students' independent choice of major. Based on students' living community, Academy should improve the development scheme of traditional administrative class and students' organization, and explore students' innovative organization and mobilization patterns matching the university's personnel training mode.

Second, broad category enrollment and cultivation emphasize students' learning initiative and subjective. Thus, universities should conduct reform of the supply front, and provide platform for individualized development. Academies can carry out new learning guidance and adaptive education, new seminars and training camps, psychological counseling, and so forth, to train students' independent thinking, the ability to select and judge, and to stimulate their subjective initiative. Academies can change the working mechanism of counselors and build a learning and research-oriented academy counselor team in accordance with the principles-students leading management, working with special focus, and highlighting a specialty.

\section{The Analysis of Impelling Academy Construction Path}

\subsection{Academy Construction Calls for United Efforts of All University Members}

There is an old Chinese saying that missions can be done when all the upper and lower classes have the same goal. The development of academy reform is a crucial part of completing university's talents cultivation support system. Additionally, the united innovative force of all teachers and students is the precondition ensuring the construction and promotion of Academy. Therefore, the academy construction needs to strengthen the top design, building the institutional structure of Academy by the joint force of teachers and students, breaking up difficulties with collective wisdom, implementing subject responsibility by discussion [4]. Academies should be encouraged to be creative and groundbreaking. Encourage people focusing on overall framework of the reform of the Academy system to think towards standard, implement details, share interactively, and thus form a vivid competing development of the situation among the Academies.

\subsection{Academies and Colleges Should Shape Joint Force to Cultivate Students}

Talents cultivation is the responsibility and mission of both colleges and Academies. Considering the role definitions of colleges and Academies, we often liken colleges to students' fathers which take charge of dominant curriculum focusing on students' utilitarian abilities such as technical skills, employment and further study. Meanwhile, we compare academies to students' mothers which are responsible for hidden curriculum like psychological counseling, developing guidance, club activities and so force focusing on students' development of non-utilitarian qualities, such as thought guidance, behavior development, and personality shaping.

Although the roles of colleges and academies should be divided clearly, their duties and responsibilities cannot be separated. Academies should plan their developing specialties, and fully gather the strength and resources of relevant colleges to meet the development needs of students. Colleges with the goal of improving comprehensive professional skills, and the Academies with the foothold of rich cultural background, must work together for the common solution of the reform and development of the Academy system. Colleges and Academies, to be specific, are required to adhere to the dialectical unity of professional education and general education, to achieve a benign interaction of subject progress and academy development, and to build a complete and systematic, scientific and efficient smooth running coupling mechanism.

\subsection{Academies Should Strengthen Ideological and Political Education Function}

Academy system provides a vast stage for cultivating morality and amplifying the ideological 
and political education. It intensifies rather than reduces the function of ideological and political education. Thus, it is an effective way to improve the quality of ideological education. In the practice of running Academy system, the ideological and political education resources are reorganized, and the education should be incorporated into Academy management service and development guidance so as to guarantee and enhance the quality of the students' ideological and political education [5].

Under the new current situation, it is necessary for the Academy system to pay attention to the needs and characteristics of the undergraduates after 95s, take the improvements of the scientific level of the Academy, and center on the traditional outstanding Chinese culture, student-teacher interaction, learning community and student community. In addition, Academy system should achieve the harmonious unity of scientific spirit and humanism through vigorous guidance as well as scientific and humanist management services, consolidate the function of ideological education, and promote a new development of talents education in universities by the new results of Academy system.

\section{References}

[1] WeiGuang Qiu. (2011) Adhere to the Combination of Comprehensive Development and Personality Development. Studies in Ideological Education, 15, 28-31.

[2] Wan Yu. (2012) Fudan University's "Accommodation Academy System" Deepens the General Education Reform. Xinhua News Agency, Sep 7th.

[3] LiXun Wu, WenQuan Feng, ZhuoNing Dong. (2015) Academy: New Carrier of "Education” and "Cultivation"-Exploration and Practice of Building the Third Classroom for the Cultivation of Innovative Talents Based on the Academy System in BUAA. Higher Education Development Study, 6, 43-44.

[4] Jun Guo. (2013) The Rise of Classical Academy and the Implications of Its Development. Journal of Higher Education, 8, 76-83.

[5] Linyan Wan, Nannan Zhang. (2015) Enlightenment of Academy System on Ideological and Political Education of College Students. Studies in Ideological Education, 12, 55-58. 